\title{
Små barns första möte med Adolf Hitler. Dagboksanteckningar från deltagande observation i det egna hemmet
}

\section{Av Stefan Arvidsson}

Mina barn är i skrivande stund 8 och 5 år. Deras kunskaper om världen och historien är inte så stora och de är fragmentariska. Det äldsta barnet, en flicka, går i andra klass och är i princip helt ointresserad av allt vad historia och skolkunskaper heter. Det mindre barnet, en pojke, går fortfarande på dagis men har ett stort intresse för andra världar och andra tider.

För kanske ett år sedan slog det mig hur väl och hur snabbt de mindre barnen kunde identifiera nazistiska symboler och att de hade en rudimentär och samtidigt kraftigt moraliserande (eller moralisk) uppfattning av nazismen. I denna text vill jag reflektera över riskerna med att som förälder reproducera en mytologisering och fetischering av nazismen.

Under mina år som doktorand på 90-talet rasade under de religionshistoriska seminarierna en debatt om värdet av så kallad postmodern eller reflexiv antropologi. Denna antropologiska skola la under påverkan från framförallt Foucaults nietzscheanska analys av vetande som vilja-till-makt stor vikt vid forskarsubjektets självmedvetande och självreflektion. Dessa reflektioner parades ofta (som hos Vincent Crapanzano, Michal Jackson och Jean-Marie Gibbal) med filosofiska utläggningar av ontologisk och epistemologisk art. Nu som då är det min uppfattning att denna skolbildning bygger på en rad slappa missförstånd av verklighetens natur och metodologisk hypokondri. Jag är dock tvingad att inse att denna text i viss mån skulle kunna placeras in i denna tradition. Inte så mycket för att jag intresserar mig för mig själv och min kulturella bakgrund, som för att empirin fungerar som ursäkt för filosofiska eller kanske bättre teoretiska reflektioner (i motsats till vad Clifford Geertz kallar "thick description" av de studerande människorna). I den följande texten har jag behållit dagboksanteckningens form, vilket indikerar resonemangens status av provisorium.

\section{Tidig september 2009}

Jag slås av hur snabbt barnen identifierar två nazistiska symboler: hakkorset och Hitler. Hur sinnligt idealistiska tolkningar vågar man göra? Är det inte något med hakkorset och mustaschen som verkligen, oberoende tid och rum, sticker ut? Handlar det verkligen bara om att vi har lärt oss se dessa som det moderna samhällets motsvarighet till medeltidens bockfot? Hakkorset, och än mer Tredje rikets flagga: det svarta korset mot den vita bakgrunden, den starkaste tänkbara kontrasten, och så de otäckt kraftfullt roterande 
vingarna. Allt omgivet av blodrött. Jag kommer att tänka på Peter Weiss teckningar av svastikan som en spindel. Det är något i hakkorset och flaggan som utmärker dem, oberoende av kulturell kontext.

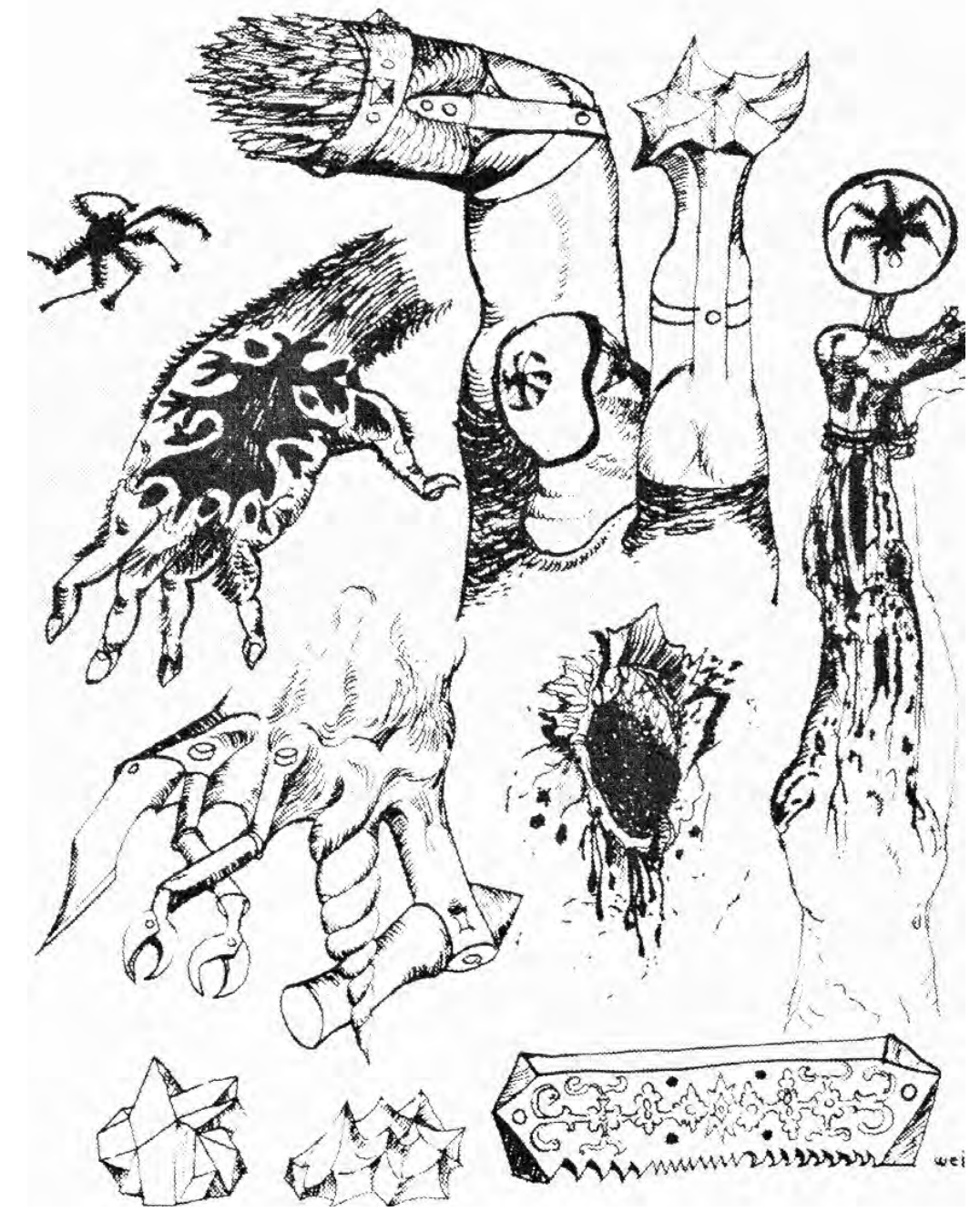

Teckningar av Peter Weiss hämtade ur Bonniers Litterära Magasin nr.6 1986 s. 367.

Inom ämnet religionshistoria älskar alla för tillfället kognitionsforskning. Av den kan vi lära att de föreställningar som lever vidare genom historien är föreställningar som är "kontraintuitiva”, det vill säga föreställningar som uppvisar drag som strider mot vad vi spontant vet gäller för verkligheten. En människa har människohuvud och därför överlever föreställningen om en människa med elefanthuvud (guden Ganesha). Vi minns det konstiga. Men föreställningar får inte vara för kontraintuitiva för då blir det så tokigt att det blir ointressant. Därför finns det ingen gud med insektshuvud. Jag är övertygad om att kognitionsforskarna har fel och det är helt andra mekanismer än det rent kognitiva som bestämmer vår föreställningar, men det där med det kontraintuitiva är ändå rätt slående i samband med hakkorset. Är det inte just lagom kontraintuitiv? Ett stabilt enkelt kors men samtidigt med optiskt luriga kvarnhjulsliknande vingar.

Men mustaschen då? Sidbenan är väl en sak - men mustaschen är ju bara idiotisk. Inte disciplinerad, kastrerad. Inte elegant, förtvinad. Inte civiliserad, ängslig. Som vuxen har man sett mustaschen användas som metonym för nazism (den ditritade mustaschen 
avslöjar George Bush som den nazist han egentlig är) eller som förlöjligande symbol i största allmänhet. Därmed har den fått ett eget liv, den har laddats. Men så kan det väl inte redan vara för barnen? Eller handlar det helt enkelt om att Hitlers nuna dyker upp i samma kontext som hakkors (och kanske bilder av tyska uniformer, rökmoln och dylikt) men att jag inte har noterat detta?

\section{Tidig oktober 2009}

Jag börjar läsa Barnens världshistoria för min son. Barnens världshistoria består av sex band som sträcker sig från "forntid" till "idag”. Det sista bandet, där läsaren bland annat kan lära sig om nazism, är 55 sidor långt. Ungefär 12 sidor ägnas åt nazismen i Tyskland. Ryska revolutionen, som kunde fungera som jämförelsematerial, får 3 sidor men kommunismens historia till 1989 sammanlagt cirka 16 sidor. De ämnen som berörs under det sammanhållna stycket om nazism i Tyskland under åren 1932-1945 är ekonomisk depression och nazistisk agitation (två sidor); statskuppen och polisstaten Tredje riket (två sidor); pogromer och koncentrationslägren (två sidor); Hitler startar andra världskriget (två sidor) samt Anne Frank (fyra sidor). Tonen är generellt saklig men avsnitten som skildrar de judiska offren, cirka hälften av de tolv sidorna, har delvis ett inifrånperspektiv och det finns utdrag ur Anne Franks dagbok vilka förstås är utformade i ett helt annat tonfall.

Det är uppenbart att författarna till Barnens världshistoria vill väcka indignation, eller kanske, bättre moralisk medvetenhet, hos läsarna. Militariseringen av Tyskland accentueras i bilderna. Inte bara uniformerna är grå, åtminstone på sex bilder är vädret gråmulet. Ingen ser glad. Mest män.

I alla berättelser som vill förmedla en moral (och finns det egentligen andra?) är beskrivningen av ondskans genesis avgörande. I Barnens världshistoria handlar det om en ekonomisk depression som kanaliseras genom nazisternas syndabockstänkande: allt dåligt kom från socialdemokrater, kommunister, fabriksägare, bankirer och kommunister: "Det var många som trodde på Hitler”. Ondska är ett begrepp som är (eller borde vara) förbjudet inom humanistisk vetenskap (eftersom det ersätter kunskapssökande med etik, istället för som sig bör bli en konsekvens av kunskapssökandets resultat). Däremot är det förstås viktigt att studera hur "ondska" hanteras på den emiska nivån, objektnivån.

För den femårige pojken finns det egentligen bara en berättelse som man måste känna till på dagis och i umgänget med andra barn. Star Wars, George Lucas filmsvit lever vidare på samma sätt som klassiska myter och liksom de bärs den upp av en stark institution (kulturindustrin); liksom de skapar den en social gemenskap (mellan framförallt pojkar) med såväl hierarkier som exkluderingsmekanismer; den ger ett mönster för handling (utklädnad, laserfäktning) samt fungerar, förstås, som diskurs - det eviga malandet om vem som är vem, vem som dödar vem, vem som blir ande, ad nauseum. Diskursens dynamik är förstås beroende av att det finns två sidor: den om slåss för det Goda och de som slåss för det Onda. De förklaringar som Star Wars erbjuder för att förstå ondska är 
(i alla fall när det gäller Anakins syndafall) dels hämndbegär, vilka riktas mot de som har mördat Anakins mor, hämndbegär som när de en gång har släppts fria tycks få ett eget liv, dels oron över att annat älskat (den gravida Amidala) också kan gå förlorat. Det sista motivet är intressant och skulle säkert kunna användas för att på individnivå förstå en del icke-fiktiv "ondska", men problemet i Star Wars är att logiken bakom steget till att gå över till den mörka sidan är svår för barn att följa.

I Star Wars har den mörka sidan ett viktigt triumfkort: sith-riddarna känner till (eller, förstår vi tittare, påstår sig känna till) konsten att övervinna döden. Med den kunskapen kan man rädda de man älskar, slita bort från Liemannens kalla, hårda grepp. Det är den möjligheten som attraherar Anakin Skywalker. Skulle det verkligen vara så fel att i en bok som Barnens världshistoria visa fram det som vanliga tyskar tyckte var NSDAP:s positiva sidor? Hade det inte varit bra med ett infrån-perspektiv på nazisterna? (Den märkliga konklusionen att folk röstade på NSDAP därför att de gillar det onda, avslöjas suveränt i Killinggängets välkända sketch om den tyska tanten som ska välja mellan det snälla, humanistiska liberala partiet och nazzzzisterna.)

Ingen ideologikritik kan vara, om vi får tro traditionen från Ernst Bloch till Fredric Jameson, fulländad om vi enbart fokuserar ideologins status-quo-skapande sida. Vi måste även lyfta fram, och kritiskt analysera, ideologins ideal, drömmar, utopier. Anakin blev inte bara sith-riddare för att han hatade de som mördat hans mor, utan därför att han hade upplevt intim kärlek och vävt drömmar runt dess framtid. Var det inte likadant med dem som stödde Adolf Hitler? Motivet med syndabockstänkandet är helt säkert centralt och bör lyftas fram. Men missar vi inte en viktig aspekt om vi inte ser drömmarna? Kanske var drömmarna inte som hos Anakin baserade på upplevelser av intim kärlek (i Klaus Theweleits Mansfantasier får vi en stark bild av extrem och ångestfull kärlekslöshet) men lika fullt baserat på upplevelser av, eller i alla fall föreställningar om, något gott. Har det någonsin existerat någon som utför bestialiska handlingar utan att på något förvrängt sätt samtidigt värna om eller ropa efter något gott?

Riskerar inte ett allt för ensidigt betonande på nazisternas "ondska" (deras låga syndabocksmekanismer) att mytologisera, närmare bestämt att demonisera. Och innebär inte en sådan mytologisering att vi gör dem till krafter bortom det historiska sammanhanget? Och, viktigare: tappar vi inte bort en hel diskussionsbit - fullt möjlig för barn att intressera sig för - med detta ensidiga fokus? Nämligen diskussionsbiten som följer på frågan om hur nazisterna kunde ha uppnått det de - innerst inne! - drömde om utan att tortera, lemlästa och mörda. Denna diskussionsbit klär så att säga av nazisterna deras armbindelförsedda uniformer och söker visa dem som verkliga, sårbara och längtande, människor. Det skulle handla om en avmytologisering i riktning mot vad existentialisterna kallade "den mänskliga situationen”.

I linje med dessa resonemang kan man kritisera den forskning om nazismen som alltför ensidigt fokuserar på bilder av manlighet, uniformer och styrka - men våldsromantik är självklart en sine qua non i all fascism! Istället bör vi kanske också plocka fram de mjukare idealbilderna, bilderna av en familj som skördar tillsammans eller en mor med 
friska barn. Jag känner nästan bara till Old dreams of a new Reich av Jost Hermand som explicit tar fasta på detta. Varje gång vi reproducerar den "manliga”, "heroiska” och militanta bilden av nazismen räcker det inte med att påtala det som något destruktivt som ledde till brutala folkmord. Vi måste också avslöja det "sköra”, längtansfulla bakom de gråa och bruna fasaderna. Det finns alltid något före, det är något som genomgår (tvingas eller är berett att genomgå) det nazistiska stålbadet. Detta något måste visas fram.

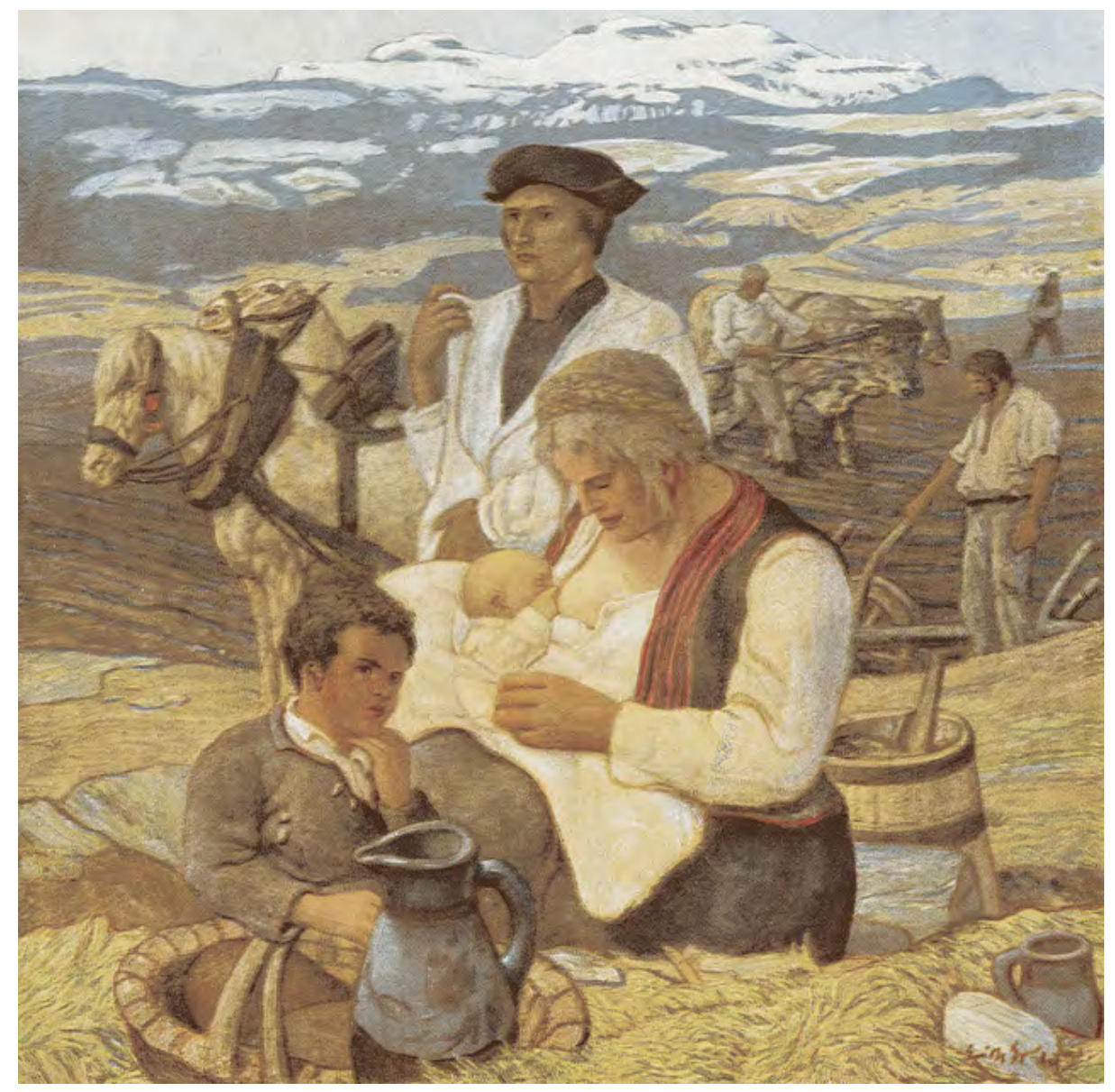

Erich Erler, "Blut und Boden” (1942). Om hur denna tavla såldes i Sverige under namnet "Vår", se Natalia Kazmierskas artikel i Aftonbladet 6/12 2012 (http://www.expressen.se/kultur/var-for-hitler/).

\section{Sen oktober 2009 I}

Läsandet och bläddrandet i Barnens världshistoria får mig att tänka på min egen barndoms och ungdoms fascination för nazismens symbolvärld. Denna fascination - som jag för allt i världen inte vill föra vidare till mina barn, men anar redan har kommit till korta med - är delvis baserad på en populärkulturell reproduktion av nazismens självbild som oomkullrunklig makt, renande stål och amor fati. Denna mytiska framställning rostar inte sönder av till exempel Forum för levande historias information om nazismens förbrytelser (även om Om detta må ni berätta är en utmärkt publikation som jag skulle gissa verkar på djupet hos många barn). Det finns en risk att den snarast förstärks genom att bli en bild av det Onda. Nej, inte en bild av det Onda, bilden per se av det Onda. 
Oron för att mycket litteratur om nazisterna demoniserar dem på ett sätt som är kontraproduktivt ligger i linje med Wim Wenders precisa kritik av Traudl Junges film Der Untergang som handlar om Hitlers sista dagar: om man visar människor som dör med sönderslitna och fula sår till höger och vänster, men vägrar låta kameran visa Hitlers döda kropp förstärker man effektivt mytologiseringen av karln.

\section{Sen oktober 2009 II}

Maktens ring kan endast smidas av den som har avsvurit sig kärlek: så lär som bekant Richard Wagner i Der Ring des Nibelungen. Tyvärr är det ju inte sant. Kärleksfulla fäder och mödrar kan vara torterare och mördare. Ändå har förstås Wagner rätt: man kan inte härska och dominera över folk utan att stänga av vissa grundläggande mänskliga känslor. Om människor inte skulle ha medfödda känslor av medlidande varför skulle vi behöva all dehumaniserande hetspropaganda? Dehumanisering av medmänniskor, inklusive de som man kanske faktiskt har en verkligen intressekonflikt, måste odlas och näras. Nazisterna kunde den konsten.

Reell förnedring, från koncentrationslägrens inferno till skamlösheten i Abu Ghraib, är, som Bruce Lincoln (2006) har argumenterat om det sistnämnda, den vanlige soldatens försök att övertyga sig själv om att den propaganda hon har utsatts för är sann. Soldaten vill övertyga sig om detta genom att iscensätta medmänniskornas förnedring: genom förfulandet av medmänniskorna "bevisas” propagandans budskap. Propagandas berättelser blir till manus för att iscensätta en teater som spelas upp med syfte att skänka regissören/publiken visshet om dess riktighet. Snacka om falskt medvetande.

Ett motförfulande kan aldrig vara humanismens bästa medel. Det kan i alla fall inte vara ett bra medel på längre sikt eller på djupet, men när det gäller mobilisering inför till exempel anti-fascistiska aktioner behövs det kanske i stunden ('Nazistsvin!").

\section{November 2009}

Mamman i familjen läser berättelserna om Katitzi för flickan och sedan även för pojken. Det handlar om berättelser som bygger på verkliga händelser från författarinnan Katarina Taikons uppväxt. I den nionde boken i serien, Z-1234, publicerad 1976, berättas det om de nazistiska förbrytelserna mot romerna. Återgivningarna, skildrade av den romerska kvinnan Zoni för Katitzi, är kortfattade men samtidigt gripande och otäcka som ett fotografi och måste äckla varje läsare, till och med sådana läsare som läst dokumentära skildringar såsom Simon Wiesenthal Mördarna mitt ibland oss (1967). Jag tycker det är värt att återge ett längre citat:

- Jag kommer aldrig ifrån det... Jag kommer alltid att vara rädd. Inte ens i sömnen lämnar dom mig. Dom kommer i drömmen. Dom förföljer mig. Med sina uniformer... Håleende, överlägsna, grymma. Människor är djävlar.

- Men du är ju i Sverige nu, sa Katitzi vädjande. Det är inte samma människor... 
- Människor är sig lika över hela världen, avbröt Zoni, det är bara tillfälligheter som avgör. Har du sett blickarna vi får av folk vi möter på gatorna, i affärerna? När jag var och handlade igår, säg jag plötsligt hur biträdet tittade på mig med samma ögon... samma blick som den man som gjorde det här.

Zoni höll fram sin nakna arm, och Katitzi sog det tatuerade numret på handleden. Det stod ett $Z$ före siffrorna.

- Varför gjorde dom så där? Frågade Katitzi.

- För nöjet att få förnedra oss... Få oss att känna oss som djur. Märkta som boskap drevs vi mot slakterierna... Gaskamrarna.[...]

- Soldaterna slet upp le Rom ur tälten och vagnarna, och dom som var för svaga eller sjuka krossade man huvudena på med gevärskolvarna. Andra sköt man. Soldaterna såg inte ens arga ut, när dom gjorde det... Likgiltiga, eller med ett överlägset håleende, en fnysning och en skalle krossade... [...]

- Från vårt gömställe kunde vi se hur le Rom ställdes upp och sköts ned med kulsprutorna. Spädbarn kastades upp i luften, och man pricksköt på dem. Mödrar försökte gömma sina småbarn under kjolarna. Soldaterna tyckte det var väldigt roligt och sköt barnen rakt igenom mödrarnas kjolar och underliv.

- Det var ett fruktansvärt blodbad.

- Och dessa mördare, förstår du Katitzi, såg inte ut som några främmande monster. Dom såg ut som folk gör mest, som vilken svensk beväring som helst, som just har ätit sin ärtsoppa. Inte annorlunda på något vis och det kanske var det mest skrämmande (21-24).

Ett barn som inte berörs av detta är redo för BUP. Förutom en allmän välvilja mot romer är det något slags kunskap om nazistisk mentalitet som barnen i den observerade familjen tycks ha med sig från Katitzis värld. (Jag minns från min uppväxtstad Tranås att folk uttryckte tillfredsställelse när en bil full med romska ungdomar från staden körde ihjäl sig, det bör ha varit några år efter att Z-1234 hade utkommit.) Man kan anta att Zonis misantropiska och oroande föreställningar - som Hanna Arendt gjort berömda i Den banala ondskan (1963, svensk översättning året efter) - om att vem som helst kan bli mördare utifrån inga speciella anledningar och utan några speciella känslor alls inte biter på av små barn. Och man kan med Zoni själv undra om djup misantropisk klagan över arten homo sapiens sapiens är uppbygglig för små barn.

Berörde, har jag anledning att tro, gjorde även Katitzis vackra och naiva heroiska önskan om att få markera sin medkänsla med Zonis öde genom att likt Zoni skriva in koncentrationslägerssiffrorna Z-1234 på sin arm. Flickan i den studerade familjen har tidigare uppvisat ett inte alltför heroiskt sinnelag (när hon såg Bröderna Lejonhjärta menade hon att hon helst skulle vilja ha varit på Tengils sida när dennes här såg segerrik ut). Jag tror att det är beteendet att vilja att stå på den goda sidan även i nederlagets stund som fängslar henne med den annars långtråkiga och tysktalande filmen Sophie Scholl - Die letzten Tage (2005). Av en slump får hon syn på denna och fascineras. Vi ser om den två gånger. Även under de rätt långa scener då Sophie samtalar med polischefen tittar hon 
med hög grad av engagemang. Jag kan bara förklara detta - med stöd från några frågor från henne vilka förstärkte intrycket: det är dilemmat (göra rätt även när det orsakar en själv lidande) som är eggande i sig.

\section{December 2009}

Efter sin fars mormor har flickan ett tyskt mellannamn. Jag har berättat lite om den kvinna vars namn hon bär liksom om hennes familj - en borgerlig Sudetendeutsch släkt som skingrades på grund av världskrigen och där många dog på östfronten. Detta intresserar henne, historia blir bara levande för henne när enskilda människor av kött och blod träder fram. När hon förstod att denna släkt var på fel sida av gränsen mellan gott och ont (en överväldigande majoritet av alla sudetentyskar röstade i valet 1935 på det nazistiska Sudentendeutsche Partei under ledning av Konrad Henlein och min mormor har berättat att hon som litet barn hade varit med om att rista in judestjärnor på hus i Karlsbad) bekymrade det henne inte nämnvärt. När hon talar med sin bästis vars farmor är judinna noteras detta enbart, men bästisen förefaller stolt över sitt judiska arv.

Hade man varit kristen kunde man vara stolt över den utvecklingen: kristendomen är ju, om man ska tro litteraturvetare René Girard, den ende ideologi som gör offret till hjälte. Medan till exempel storslagna berättelser såsom de pseudohistoriska texterna i Den hebreiska Bibeln ("Gamla Testamentet”) eller Mahabharata eller Shahname står på segrarnas historia och hyllar den starke, försvarar Nya Testamentet den förtrampade och avrättade. Det är sannerligen en historisk ironi att det folk som genom två årtusenden har slaktats av kristna för att ha dödat juden Joshua nu upphöjs av kristna till offret per se.

\section{1 mars 2010}

För några veckor sedan visade jag barnen boken Om detta må ni berätta med dess fruktansvärda bilder. Jag minns att de tittade på bilderna med stort intresse, men det är inget de har återkommit till. Berättelserna om lidandet tycks starkare än bilderna av lidande. När jag idag visar snarlika bilder på likviderade armeniska barn från 1915 års folkmord (som nu Sveriges Riksdag har slagit fast att det handlar om) gör ingen av dem någon uttalad koppling till bilderna i Om detta må ni berätta, fast de på många sätt är så lika (speciellt ur deras horisont torde de sticka ut eftersom de inte är vana vid svart-vita bilder). Är det judiska i berättelsen om Förintelsen viktigare för dem än det systematiska dödandet?

Jag minns en debatt på Smålands nation i Lund någon gång i början av 1990-talet då Sven Lindkvist talade om sin nyutkomna bok Utrota varenda jävel. Lindkvist ville med boken visa att Förintelsen inte vara ett så unikt brott som det framställs. I själva verket ingick Förintelse i ett tidstypiskt mönster av kolonial politik och evolutionistisk rasism. Den första frågan Lindkvist fick efter sitt framförande var: "Är du inte rädd att få vänner du inte vill ha?” Frågan var förstås angelägen och relevant och samtidigt riskerade den att - genast - förflytta en vetenskaplig diskussion till en politisk. Samma fråga dyker upp i mitt - och säkert många andras huvud - varje år som det ska vara åminnelse av Kristallnatten och den politiska vänstern (som jag själv tillhör) vill göra denna åmin- 
nelse mer samtidsrelevant genom att omforma den till en manifestation mot alla slags rasism och xenofobi.

"Unikt” är en term som, påpekar vi religionshistoriker ofta när kristna teologer talar om det unika med Jesus, bara har en mening mot bakgrund av en regel, ett mönster, en fond. Jämförandet har inte, som den amerikanske religionshistorikern Jonathan Z. Smith har understrukit, två utan tre element: måttstocken måste till. I sökandet efter "det unika med kristendomen" förflyttas hela tiden måttstocksfonden: "Det är unikt att Gud blev människa." "Nej, det var vanligt under antiken och Indien kryllar av avatarer." 'Det är unikt att Gud dog och återuppstod.” "Nej, det gjorde ju även andra antika gudar såsom Dumuzi, Adonis och Horus." "Det är unikt att han hette Jesus!" "Jo..." Vilken fond är relevant när man ska avgöra om Shoah var unik eller egentligen hör samman i samma kategori som t.ex. folkmordet på armenier, på hererofoket Tyska Sydvästafrika eller på romer under andra världskriget?

\section{2 mars 2010}

Vad vill jag att barnen ska lära sig? Antisemitismen är totalt frånvarande i deras liv judar är ingen relevant grupp i deras dagliga liv (det är däremot "muslimer", "invandrare"). Att ha judiskt påbrå är, för till exempel flickans bästis, en källa till stolthet, inte skam. Vissheten om offerrollen förädlar - vackert så! Man skulle förstås kunna argumentera att vi ska lära av Förintelsen för att inte upprepa det i framtiden. Det judiska i förintelsen blir sålunda tillfällig, mindre relevant, och lärdomen generaliseras till att gälla olika avvikande, minoritetsgrupper. Visst. Men bör vi inte samtidigt ha en närmast religiös humanistisk hållning gentemot det förflutna, gentemot de döda? Är inte historia att lyssna på de dödas röster, inte för att använda dessa, utan för att helga dem? Vördnad, är det den gamla dygden, vi vill förmedla? Och vördnad är inget allmänt: den är riktad mot individer av kött och blod, drömmar och känslor, mot just exakt det offret, just den judinnan!

Konstvetaren Max Liljefors har i en fantastisk artikel (2004) visat hur konstnären Corrado Cagli utgår från fotografier på massgravar i Buchenwald och sedan i sina målningar placerar in de döda i ett centralperspektiv som, med Liljefors ord, förvandlar de dödade (eng. victim) till offer (eng. sacrifice). Därmed upphöjs deras död till meningsfullhetens sfär, det gudomligas ljus strålar ner på dem. Är det kanske också vårt uppdrag? Walter Benjamin: "Det är mer ärofyllt att hedra minnet av de namnlösa än av de berömda. Historisk konstruktion är ägnad åt de namnlösas åminnelse.” Detta är en nytta med historien som Nietzsche inte vill se. Vördnad låg honom inte för.

\section{3 mars 2010}

Det är en recension av Salomon Schulman av Henrik Bachners Judefrågan. Debatt om antisemitism i 1930-talets Sverige i dagens Sydsvenskan. Jag visar barnen en bild där en Furugård-nazistisk sätter upp en antisemitisk affisch på en svensk-judisk affär. Barnen måttligt intresserade. 


\section{7 mars 2010}

Flickan berättar att en pojke på skolan har en storbror som är nazist (vilket förmodligen bara är ett uttryck eftersom storbrodern är, uppskattar jag, ungefär 12 år gammal). Hon berättar att ingen förstod vad "nazist" betydde - ingen förutom hon. Njutningen av att vara den-som-vet sken tydligt igenom, liksom, kanske, glädjen av att påpeka detta för hennes historieintresserade och anti-nazistiska pappa. Det fanns därtill en antydan till indignation hos flickan över att de andra barnen (mellan 7 och 9 år gamla) inte kände till "nazist".

Enligt den amerikanske religionshistorikern Bruce Lincoln (1994) kan myt definieras som en berättelse som tillskrivs auktoritet inom en bestämd social grupp. Detta innebär, som ett minimum, att det handlar om en berättelse som även om individerna i gruppen inte kan återberätta berättelsen i sin helhet eller känner till alla detaljer i den, vet att de borde känna till. I denna bemärkelse är det uppenbart från exemplet att berättelsen om nazismen är en myt (i bemärkelsen "berättelse med auktoritet").

\section{1 april 2010}

På vägen till tåget till Växjö kom jag att tänka på den franske litteraturvetaren René Girards teori om mimetiskt begär. Enligt Girard föds människor utan begär och det är först genom att iaktta vad andra trånar efter som hon (men det är nog snarare en han hos Girard) börjar begär något (mimetiskt härmande de andra). Det leder emellertid till problem eftersom alla då vill ha samma sak. För att hindra konflikt och socialt sönderfall börjar därför gruppen att invertera det mimetiska begäret: de börjar avsky samma sak. Det kan alla göra samtidigt. För Girard är detta förklaringen till fenomenet syndabockar (gr. farmakoí).

För barnen i den observerade familjen, men detta är inte heller svårt att iaktta genom att under ett par månader läsa rikets ledar- och kultursidor, är nazisterna de stora Onda. Skulle man kunna se detta som att det svenska samhället svetsar sig samman genom att se nazisterna som ett slags syndabockar? Svenskar har kanske mycket lite gemensamt. Inga gemensamma drömmar. Inga gemensamma värderingar. Men vi har en gemensam fiende: nazisterna. Denna hypotes vederläggs emellertid av det faktum att den samtida berättelsen om nazismen inte ska förklara några grundläggande sociala missförhållanden. Syndabockar ska ju beskyllas för något - för att därmed skapa social sammanhållning eller, sett från cyniska makthavares vinkel i alla fall, avleda medborgarnas blick från de reella orsakerna till de sociala problemen. Men demoniseringen av nazisterna tjänar i vårt samtida samhälle inte till att skyla. Varför inte? Jo, därför att vi inte har några "grundläggande sociala missförhållanden". Vad skulle vi beskylla nazisterna för? Det finns förvisso många "grundläggande sociala missförhållanden" vi skulle kunna lansera (hotande miljökatastrof, meningslös arbetslöshet, globala orättvisor, eskalerande varufetischism etc.) men det görs ju sällan. Samhället är i grund och botten, det är det underförstådda antagandet i all politisk retorik som tas på allvar idag, sunt och till och med perfekt ordnat. 
Slutsatsen måste bli att pratet om nazisternas förbrytelser och ondskefulla ideologi, ett prat som når de lägsta åldrarna i Sverige av idag, tjänar som ett spectre, som ett spöke för att skrämma medborgarna. Vad ska de frukta? Missnöje uttryckt politiskt? Förmodligen, men barnens lärdom är nog inte denna.

\section{7 april 2010}

Vid läggdags kommer jag och flickan att prata om våld. Hon drar sig då till minnes vad jag berättat om "Operation Walküre" - filmen Valkyrie (2008) står näst intill Sophie Scholl - Die letzten Tage i bokhyllan - om hur en tysk officer misslyckades med att döda Hitler eftersom någon flyttade portföljen med bomben. "Det var synd att han misslyckades.” Jo, det var det.

Man lär självklart barn pacifism, men frågan om när, om någonsin, våld är berättigat har aktualiserats flera gånger när vi talar om nazismen. Särskilt sonen är särskild förtjust i våld - eller snarare hot om våld - som problemlösare. Ska jag bekräfta barnens våldsinstinkt mot nazisterna eller är detta snarare ett utmärkt tillfälle att prata om att "ingen egentligen är ond” och "Pappa Alois slog lille Adolf”? Om man tillåter eller till och med uppmuntrar barnen att hysa och uttrycka våldsam aggressivitet mot nazister finns det då inte en risk att barnen, med tanke på det ringa antalet nazister i dagens Sverige, odlas att tro att fienden bara finns i en sagovärld? Om det ska vara någon mening med att barnen vill sätta en kula i huvudet på någon bör det väl vara i en levande fiende? Den pacifistiska linjen alltså? Om man inte trodde, som jag gör, att det finns ett antal högst reellt kroppsliga människor som allt hastigare driver vår värld mot Gehenna skulle det väl vara svaret.

\section{2 maj 2010}

Igår ombads jag via en kollega att skriva några meningar om en SS-affisch som skulle visas på ett museum. Jag kom då att tänka på att barnen inte talat om nazism på länge. Men om tv-programmen Barda, Wild Kids och annan populärkultur berättar och återberättar de ständigt. Jag har den bestämda känslan av att de vet att berättelserna om nazism är myter (auktoritativa berättelser som något slags "vi” förväntas känna till och dra lärdom av) medan det andra bara är sagor, underhållning (vilket förstås inte utesluter att de är alltigenom impregnerade av ideologiskt begärsstrukturerande ideal).

Men så idag började barnens mamma tala om att hon tyckte mycket om en pojke som går i flickans klass. Han är en av få med invandrarbakgrund (mamman från Peru och pappan från Danmark), talar lite släpig och knackig svenska och är lite rultig. Mamma sa att hon tyckte mycket om pojken för att han är lite "annorlunda" och lite "gammaldags". "Du är ju nazist!" blev flickans kommentar. Var det självaste utpekandet av någon som annorlunda, även om detta inte var ett utpekande med negativa associationer, som aktualiserade berättelserna om nazisternas fördomar? Tänkte hon att varje annorlundahet är ett stigma och att annorlundahet därför helst bör förtigas? Flickan har ett ganska komplext förhållande till det normala: samtidigt som hon inte klär sig normalt eller är 
speciellt mån om att vara människor till lags, är hon själv blixtsnabb att etikettera avvikande beteende som "efterblivet" och avvikande personer som "efterblivna". Var det istället medvetenheten om att pojken är "rasligt" annorlunda, man kan lätt se det peruanska "indianblodet" i hans utseende, som utlöste hennes kommentar?

I vilket fall som helst tycker jag man kan se att berättelsen om nazismen hade lagt sig på "rätt ställe” i hennes hjärna: det allvarsamma, ideologiskt-funktionella stället.

\section{1 maj-1 juni 2010}

Ship to Gaza, med en vän och kollega ombord, kapas och israeliska soldater dödar frivilliga hjälparbetare. Jag åker till Malmö för att manifestera och hoppas på närvaron av inte alltför många islamister och antisemiter. Där är inga. Istället talar en imponerande judinna om sin sorg över Israels politik inför en lugn och blandad samling.

Jag berättar för barnen om dödskjutningarna, om min oro för min vän och om mina åsikter om konflikten. Flickan förklarar för mig, med något slags märklig njutning, att han som jag känner, eller möjligen hans hustru, säkert har blivit skadade och får "sitta i rullstol resten av sitt liv". (Hur kan det vara att inte verklighetens dramatik, som jag försökte förmedla och som jag är rätt säker på märktes i min blick, mitt tonfall och mitt kroppsspråk, ändå inte blir tillräckligt dramatiskt...) Pojken förklarar, efter en viss stunds betänkande, att han tycker synd om både de som ville hjälpa "araberna" eftersom de blev skjutna och misshandlande och om judarna "efter allt som har hänt dem".

Jag undrar om barnens uppfattning om judar är så polariserad som den lätt skulle kunna bli: offer för nazismen, men förövare idag (om vi antar att barnen har svårt att inte tänka i ekvivalensen ”jude = Israel = israeliska regeringen”). Det är inte lätt att förklara att fast Israel styrs av judar är det inte alls så att all judar i Israel stöder regeringens politik och att det finns många judar utanför Israel som inte heller stöder den! Inte ens mina svärföräldrar, under en livstid aktiva socialdemokratiska kommunalpolitiker, kunde låta bli att säga att "judarna” har gjort ditten och datten när den israeliska regeringen beordrade ett av alla sina våldsdåd.

Runt mitten på det första årtusendet före kristen tideräkning skapade några hebreiska präster berättelserna om Israel/Kanaan/Palestina som ett utvalt land, given åt deras förfader Abraham av guden Jahve-Elohim. Samtidigt spann ugariter, fenicier och filistéer snarlika myter om sina landområden, sina förfäder och sina gudar. Jag oroas över att jag kommer att vidarebefordra denna fetischering av "Det heliga landet” och att judarna även i framtiden ska fortsätta att ses som ett (på gott eller ont) unikt folkslag. Är man humanist måste man vägra detta. I vilken urgammal mytologi finns det inte en fetischering av ett landområde? Eller av ett visst berg eller en viss sjö? Det är legio. Att dessa mytologiseringar fortsätter att spela en politisk roll idag - från "ariernas" Bharata i Sydasien till mormonernas Nya Jerusalem i USA - är beklämmande.

Hur av-fetischerar man något? Hur av-fetischerar man judarna? Nazismen vilar ju på sätt och vis på denna "övervärdering” av en människogrupp, detta överdrivna intresse. 


\section{6 juni 2010}

Jag läser grekiska myter för barnen. När jätten Antaios (som för övrigt gav namn till en tidskrift med bland andra Ernst Jünger som redaktör) lyfts av Herakles och förlorar kontakten med jorden, hans moder, blir han helt kraftlös.

Den nazistiska kärleken till jorden har väl ytterst sin rot i jordens materiella nytta, men det är ju knappast de som sliter med jorden som är benägna att upphöja den till ett mytiskt element. Det förutsätter alienation. Det är väl inte en slump att många av de mest militanta israeliska bosättarna är uppväxta i amerikanska storstäder. Inte heller ligger det en svärmisk estetisk-sinnlig nostalgi bortom den fascistiska Blut-und-Boden-kulten. Nazister är bara romantiker så länge det handlar om form, inte om innehåll.

Mytologisering är platonism. Det är att transportera det tillfälliga till det eviga, att dubblera verkligheten i ett original och en kopia. Myterna om Herakles visar grekernas historiskt tillfälliga heroiska ideal som eviga ideal, något för alla unga grekiska män att imitera. Det handlar om en dialektisk rörelse från den tillfälliga jorden till den eviga himlen och tillbaka. Men handlar kanske den mytiska jorden om motsatt rörelse? Inte från den eviga himlen till den tillfälliga jorden och tillbaks igen, utan från den tillfälliga jorden ner i underjorden och tillbaks igen. Motsatsen till eviga ideal är kanske inte det verkliga livet där idealen ständigt kommer på skam, utan det tillstånd där uppspaltning mellan det ideal och det reala ännu inte har skett. Jag tänker på Richard Nolls bok om Carl-Gustav Jung och den vurm för det ktonska, underjordiska, undermedvetna och matriarkala som han finner hos proto-nazistiska grupper. Inte Wotans himmelska ideal. Inte Vaterland. 'Die Mütter! Die Mütter! - 's klingt so wunderlich!' (Goethe, Faust).

Heimat. Längtan, men inte efter romantiskens sublima objekt, utan efter det ickealienerade. ”Jag längtar marken, jag längtar stenarna där barn jag lekt.” Fast Heidenstam var ju rätt mörkblå... Kärlek till jorden, till hembygden, är i vilket fall som helst inte detsamma som nazism. Längtan efter att komma hem är kanske en inneboende mänsklig känsla - eller så är den bara en historiskt tillfällig känsla. Kanske bara finns i alienerande klassamhällen: "... hembygd (Heimat). Det är marxism”, skriver Ernst Bloch! Men var går gränsen mellan en mänsklig längtan hem och chauvinistisk fetischism?

\section{8 juni 2010}

Några få gånger har det slagit mig att barnen gör självständigt och originellt bruk av mytiska figurer för att föra fram en åsikt eller ett argument (så som när flickan den 22 maj hävdade att mamman var nazist). Ikväll stötte jag på det igen. Jag läste en hästbok för flickan som handlar om en flicka som tvingas lönearbeta för att kunna ha råd att ha kvar sin häst. I boken stod det att flickan "bara kunde tänka på pengar" (eftersom hon fruktade att annars bli tvungen att sälja sin älskade Santos). ”Hon är som Krösus [Sork], fast på ett annat sätt" kommenterade flickan. Figurer ur Bamse kan alltså användas som förståelseikoner och därmed upphöjas till mytologins sfärer. I en tid av massmedialt överflöd är det annars få berättelser som erhåller en mytisk status i den av Bruce Lincoln 
definierade meningen av att vara berättelser som alla förväntas känna till. Har historierna om nazismen och Förintelsen en plats där? En särpräglad plats märkt av "på riktigt"?

Sedan mer än tjugo år tillbaka tävlar recensenter på landets kultursidor om att fördöma barnböcker som fördömer: pekpinnar är ett gissel, uppbyggelse ett misstänkliggjort motiv bakom att skriva en bok för barn. Associerad med den irriterande pekpinnepedagogiken är realismen. Följden har blivit en uppsjö av fantasifulla, mystiska och tokiga barnböcker som alla slår knut på sig själva för att inte vara pekpinnar: men lika fullt predikar "Tro på dig själv!", "Allt är möjligt!" "You can do it!”. Det är signifikant att på barnavdelningen på Lunds stadsbibliotek har fantasy-böcker och deckare för barn i åldrarna 6-12 fått egna avdelningar.

Kan det vara så att berättelsen som nazismen intresserar - till och med i formen av filmen om Sophie Scholl - genom det enkla faktum att föräldrarna, övertygande, förklarar att denna ondska är reell? Få skulle väl protestera om jag sa att barn behöver höra både om det fantastiska och om det verkliga. Det är olyckligt om alla berättelser som barn kommer i kontakt och som är fantastiska är (förment) apolitiskt "kulturella”, medan de som det kommer i kontakt med som är realistiska är politiska. Vilka potentialer går vi inte miste om när vi underlåtit att ge barnen en aning om att det politiska kan vara fantastiskt, att det fantastiska inte sällan är politiskt, att det verkliga inte alltid är politiskt och att det nuvarande politiska inte är det enda verkliga!

\section{0 september 2010}

På väg hem från skolan börjar barnen tala om den religiösa föreställningen om kropparnas återuppståndelse. Flickan oroas av tanken på att då kommer ju också Adolf Hitler att återuppstå. Hon drar slutsatsen att det bästa vore nog om vi, hennes familj, fick bestämma vilka som ska återuppstå och vilka som får ligga kvar i jorden.

Det är förstås helt rätt att det viktigaste beslutet handlar om vilka som tillåts återuppstå och vilka som för alltid förblir dolda av jorden, de människor som för alltid är och förblir bortglömda. Men det är nästan lika viktigt hur vi låter de döda återuppstå. Även "monster" måste leva vidare i vårt kollektiva minne som människor av kött och blod, som människor med drömmar och begär. Till skillnad från Adolf Hitler och Anne Frank kommer de flesta nazistiska förövarna och deras offer av romer och judar, kommunister, socialister och anarkister, homosexuella, efterblivna och handikappade att bli kvar i jorden. Glömda till den dag på allt ska uppenbaras, om man tror på sådant.

Ska vi människor kunna känna oss hemma på jorden måste vi ständigt påminna om att det är människor som vilar i stoffet - en del dog vackra, andra förvridna, men alla startade sina liv i samma hjälplösa skönhet. Bara med det i bakhuvudet kan vi hejda den eviga mytologiseringen av nazismen som redan nazisterna själva skapade, förmedlade och som de fortfarande livnär sig på. 


\section{REFERENSER}

Ahlbom, Jens, Nyberg, Anders \& Öhman, Christer (red.) (2000), Barnens världshistoria. D. 6, Skyttegravar \& bildskärmar. Stockholm: Rabén \& Sjögren.

Arendt, Hannah (1996), Den banala ondskan: Eichmann i Jerusalem. [Ny utg.] Göteborg: Daidalos.

Benjamin, Walter (1974), Gesammelte Schriften. Bd 1, [Abhandlungen]. 1. 1. Aufl. Frankfurt am Main: Suhrkamp.

Bruchfeld, Stéphane \& Levine, Paul A. (2003), -om detta må ni berätta-: en bok om förintelsen i Europa 1933-1945. 3., rev. uppl. Stockholm: Forum för levande historia.

Burkert, Walter, Girard, René, Smith, Jonathan Z. \& Hamerton-Kelly, Robert (red.) (1987), Violent origins: Walter Burkert, René Girard \& Jonathan Z. Smith on ritual killing and cultural formation. Stanford, Calif.: Stanford University Press.

Horster, Detlef \& Bloch, Ernst (1981), Utopi och materialism: en introduktion till Ernst Blochs filosofi. Göteborg: Röda bokförlaget.

Hermand, Jost (1992), Old dreams of a new Reich: volkish utopias and national socialism. Bloomington: Indiana University Press.

Jameson, Fredric (1994), Det politiska omedvetna: berättelsen som social symbolhandling. Stockholm: B. Östlings bokförlag Symposion.

Liljefors, Max (2004), "Från jordbävning till byggnadsgrund: mytiska inslag i minnet av Förintelsen”. I Berggren, Åsa, Arvidsson, Stefan \& Hållans, Ann-Mari (red.) (2004). Minne och myt: konsten att skapa det förflutna. Lund: Nordic Academic Press.

Lincoln, Bruce (1994), Authority: construction and corrosion. Chicago: University of Chicago Press.

Lincoln, Bruce (2006), Holy terrors: thinking about religion after September 11. 2. ed. Chicago: University of Chicago Press.

Nietzsche, Friedrich (1998), Om historiens nytta och skada: en otidsenlig betraktelse. Stockholm: Rabén Prisma.

Noll, Richard (1997), Jung-kulten: en modern mysteriereligions födelse. 1. uppl. Stockholm: Ordfront.

Schulman, Salomon (2010), Recension av Henrik Bachners Judefrågan. Debatt om antisemitism i 1930-talets Sverige. Atlantis. Tillgänglig på http://www.sydsvenskan.se/kultur-och-nojen/article640372/Den-svenska-svansen.html

Smith, Jonathan Z. (1990), Drudgery divine: on the comparison of early Christianities and the religions of late antiquity. Chicago: The University of Chicago Press.

Taikon, Katarina (1976), Katitzi Z-1234. Nacka: Tai-Lang Theweleit, Klaus (1995), Mansfantasier. Stockholm: B. Östlings bokförlag Symposion.

Wenders, Wim (2004), 'Tja, dann wollen wir mal". Die Zeit. Tillgänglig på http://www.zeit.de/2004/44/Untergang_n

Wiesenthal, Simon (1967), Mördarna mitt ibland oss. Stockholm: Bonnier. 